\title{
THE EDUCATIONAL REINTEGRATION OF THE REMIGRANT PUPILS IN ROMANIAN SCHOOLS. CASE STUDY IN VRANCEA COUNTY
}

REINTEGRAREA EDUCAȚIONALĂ A COPIILOR REMIGRAȚI ÎN ȘCOLILE ROMÂNEȘTI. STUDIU DE CAZ ÎN JUDEȚUL VRANCEA

\section{Florentina CIOMAGA}

\author{
Journal of Pedagogy, 2019 (2), 85 - 105 \\ https://doi.org/10.26755/RevPed/2019.2/85
}

The online version of this article can be found at: http://revped.ise.ro/category/2019-en/

\section{(1)(1)(2) (2)}

This work is licensed under the Creative Commons Attribution-NonCommercial-ShareAlike 4.0 International License. To view a copy of this license, visit http://creativecommons.org/licenses/by-nc-sa/4.0/ or send a letter to Creative Commons, PO Box 1866, Mountain View, CA 94042, USA.

Published by:

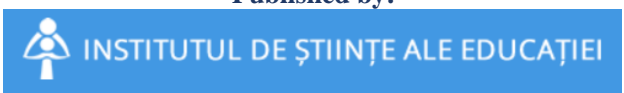

http://www.ise.ro/

Further information about Revista de Pedagogie - Journal of Pedagogy can be found at:

Editorial Policy: http://revped.ise.ro/editorial-policy/

Author Guidelines: http://revped.ise.ro/the-writer-guide-2/ 


\title{
THE EDUCATIONAL REINTEGRATION OF THE REMIGRANT PUPILS IN ROMANIAN SCHOOLS. CASE STUDY IN VRANCEA COUNTY
}

\author{
Florentina Ciomaga* \\ University of Bucharest, \\ Faculty of Psychology and Educational Sciences, \\ Bucharest, Romania \\ florentinadudu@yahoo.com
}

\begin{abstract}
The educational system in Romania is facing the new challenge of reintegrating the children that returned in their home country after a period of migration, and the update in the educational procedures is becoming more and more important as the number of the remigrant children is rapidly increasing, the most recent estimations mentioning 150,000-180,000 (Brebule , 2018).

This research investigated the social perception of the remigrant pupils in the educational field (native pupils and teachers) and the potential changes that teachers, schools and the system could implement (from specific activities to institutional update and development of new didactic instruments). The research methodology was quantitative, based on a questionnaire with Likert type scales.

Previous researches in Vrancea county showed the psychological, social and educational effects of remigration, but the updates in the educational system to better respond those needs is more dependent on their perception by the decision makers (teachers and school management) and by the native children. Ideally, the social perception should adequately reflect the educational reality. Still, what happens if the perception of the native children and teachers does not reflect reality? What happens if the majority of children could not identify the problems the remigrants face after returning to Romania? What if the teachers, when planning, implementing and evaluating the educational activities, don't rely on an adequate knowledge of the difficulties that remigrants have to face, can they support the educational system to better respond to the specific needs of the remigrants?
\end{abstract}

PhD. Candidate, University of Bucharest, Faculty of Psychology and Educational Sciences, Bucharest, Romania. 
Keywords: educational reintegration, remigrants, school development.

\section{Rezumat}

Sistemul educa ional românesc este în fa a unei noi provocări reprezentate de reintegrarea copiilor care se întorc în ara de origine după o perioadă de migra ie, iar dezvoltarea politicilor şi procedurilor educa ionale devine din ce în ce mai importantă în contextul în care numărul copiilor români remigra i este în creştere rapidă, cele mai recente estimări men ionând 150.000-180.000 (Brebule ,2018). Cercetarea a investigat percep ia socială a copiilor remigra i în sectorul educa ional (percep ia copiilor nativi şi a profesorilor) şi poten ialele schimbări pe care profesorii, şcolile şi sistemul educa ional le pot implementa (de la activită $i$ specifice la dezvoltarea institu ională şi dezvoltarea unor instrumente didactice). Metodologia de cercetare este cantitativă, bazată pe un chestionar cu scale Likert.

Cercetări anterioare desfăşurate în jude ul Vrancea au eviden iat efectele psihologice, sociale şi educa ionale ale remigra iei, însă adaptarea sistemului educa ional la aceste nevoi este mai degrabă dependentă de modul în care sunt percepute de către factorii de decizie (profesori, personalul de conducere) şi de către copiii nativi. În mod ideal, percep ia socială ar trebui să fie cât mai apropiată de realitatea educa ională, însă ce se întâmplă dacă percep ia copiilor nativi şi a profesorilor nu corespunde realită ii? Ce se întâmplă dacă majoritatea copiilor nu poate identifica problemele pe care copiii remigra i le au în readaptarea după revenirea în România? Dar dacă profesorii, atunci când planifică, implementează şi evaluează activită ile educa ionale, nu au la bază o cunoaştere adecvată a dificultă ilor pe care copiii remigra i le întâmpină, pot sprijini sistemul educa ional pentru a răspunde mai bine nevoilor specifice ale remigran ilor?

Cuvinte-cheie: dezvoltare şcolară, reintegrare educa ională, remigran $i$.

\section{Introduction}

The first research on the psychological and educational effects of remigration on the Romanian pupils (Luca, Foca, Gulei \& Brebule , 2012) mentions a first estimation of the number of the remigrant children in Romania, based on the official numbers from the Ministry of Education, considering that around 30,000 Romanian children returned home between January 2008 and May 2012.

Luca, Foca, Gulei and Brebule (2012) also mention the difficulties in the adaptation of the remigrant children in the Romanian schools, difficulties 
that are harder to understand as Valtolina (2013) mentions that Romanian children adapt very well in Italian and Spanish schools (including the school performance), but they have serious difficulties after returning to Romania. To explain this, Luca, Foca, Gulei and Brebule (2012) quoted the results of their focus group with the educational specialists (teachers and school counsellors) that showed that the educational intervention to facilitate the reintegration of the remigrants was, at that moment, based on individual expertise and insight of teachers, generalizing their expertise in working with "children left behind" (children with one or both parents working abroad), lacking a general strategy and specific resources and knowledge about remigration.

This first research also provided a general profile of the Romanian remigrant children, characterizing them as "speaking a foreign language, familiarized with another lifestyle and missing that lifestyle, appreciated in the host country for their performances and knowledge, having a medium or high anxiety level, fearful, hesitant in their relations with adults and peers, without a constant interest in social relationships and peer involvement, with low self-confidence and low aspirations, including school expectations, that usually repeat at least one class they graduated abroad without understanding why this happens" (Luca, Foca, Gulei \& Brebule , 2012).

More recent researches (Brebule , 2015, 2018) realized a more in depth analysis of the psychological and educational issues of the Romanian remigrants, but also a new estimation of the total number of children returning to Romania (this time based on international statistics and official statistics of other countries regarding the number of the Romanian children leaving that country to go back to Romania). Brebule (2018) estimated that around 150,000-180,000 Romanian children returned home between 2008 and 2015 after a shorter or longer migration period.

More specifically, the author mentions that, according to the specific data from the Vrancea County School Inspectorate, in 2016 there were 1210 pupils re-enrolled in the Romanian educational system after returning from abroad, representing $2.52 \%$ of the total county school population (according to the author, the real number could be much higher as the school inspectorate has no information about the children returning to Romania before the age of $6 / 7$ and has no reason to report to the educational authorities). 
In terms of psychological issues of the Romanian remigrant children, Brebule (2018) mentions low self-esteem and high anxiety (especially social phobia and separation anxiety), a particular coping style (focused on blaming himself or his family for his situation) and high level of some disadaptative cognitive schemes.

In terms of educational issues of the Romanian remigrant children, Brebule (2018) mentions: lower ability in understanding texts (even if they understand and speak Romanian language), a learning style based on individual efforts and not expecting specific tasks/instructions, lower academic motivation and higher evaluation anxiety.

The author mentions that most of the psychological and educational issues of the remigrants fade with time, while some remain constant or even become more intense. In this context, Popoiu, Gherasim and Brebule (2018) showed that counselling has a positive impact on the psychological issues (contributing to personal development, self-government, optimizing the coping strategy and reducing the anxiety) and educational difficulties (optimizing the study strategy, increasing the academic motivation and decreasing the evaluation anxiety) and suggested the importance of a systemic strategy of schools (focused on counselling for remigrant pupils and consultancy for parents and teachers) to facilitate the reintegration of the remigrant children.

The educational effort to facilitate the reintegration of the remigrants in Romanian schools is based on their right to have access to education that respects and harnesses their cultural identity, as stated by the UNESCO Universal Declaration on Cultural Diversity: "all persons are entitled to quality education and training that fully respect their cultural identity; and all persons have the right to participate in the cultural life of their choice and conduct their own cultural practices, subject to respect for human rights and fundamental freedoms". In this respect, Brebule (2018) also mentions that any effective intervention to help remigrant children should be based on the real understanding of the psychological, educational, social and cultural issues associated with remigration. 
In this context, our research is focused on investigating the perception of the educational actors (pupils and teachers) on the effects of remigration and the specific actions that schools could implement in order to facilitate the reintegration of the remigrant children: activities to be organized, instruments to be developed and used.

\section{Research methodology}

The research was carried out in September 2018-August 2019, focusing on the valuable insights it will bring in the process of developing specific methodologies to facilitate the reintegration of remigrants, based on a deeper understanding of the way pupils and teachers think about the necessary educational methodology.

\subsection{Specific concepts}

Remigrant children are considered those that return to Romania after a period spent in another country with the intention of staying there (Brebule ,2018; Luca, Foca, Gulei \& Brebule , 2012). Those children faced two successive migration situations, once going from their home country to another country, and second coming back from the host country to the country they were born into.

Native children are considered those that never migrated outside the country they were born in (Brebule , 2018). This definition does not exclude any international experience (like tourism, international visits, etc.), but excludes only the children that don't have a migration background.

\subsection{Objectives}

The research is based on the investigation of the social perception that the "native" pupils and teachers have regarding the remigrant pupils and their needs, but also regarding the most effective activities and tools that schools could use / implement in order to facilitate the reintegration of the remigrants. 
The objectives of the research were:

1. analyse the specific psychological, cultural and educational needs of the remigrant children, as perceived by the native pupils and the teachers;

2. identify the most relevant activities that schools could implement in order to help remigrant pupils reintegrate in our educational system;

3. identify the most effective instruments that schools could develop and use to facilitate the school adaptation of the remigrant children.

\subsection{Measures}

The research methodology is quantitative and is based on a questionnaire with Likert-type scales that focused on investigating five different aspects: a. the specific needs of the remigrant children (as the native children and the teachers perceive them), focusing on: psychological and social needs (low self-esteem, anxiety and other negative emotions, approval seeking behaviours, low interest for social relations and social participation); cultural needs (limited knowledge of local social rules and customs, the regret for the life-style in foster country, linguistic difficulties and communication difficulties); educational needs (low motivation for school activities, evaluation anxiety, limited expectations of their school performance, difficulties in integrating into school groups). The reliability of the scale was evaluated with Cronbach's alpha coefficient of internal consistency (Cronbach, 1951), alpha for 15 items being 0.684, proving an acceptable reliability of the scale as it is bigger than 0.6 (Cortina, 1993).

b. the effects of remigration in terms of educational behaviour (as the native children and the teachers perceive them), focusing on: skipping classes and eventually quit school, having a limited academic performance, developing limited skills and competencies (less than planned), limited involvement in extracurricular activities. The reliability of the scale was evaluated with Cronbach's alpha coefficient of internal consistency (Cronbach, 1951), alpha for 4 items being 0.644, proving an acceptable reliability of the scale as it is bigger than 0.6 (Cortina, 1993). 
the native children and the teachers perceive them), focusing on: linguistic preparation classes, additional classes and activities for some school subjects, extracurricular activities and learning in informal context activities, project based learning experiences, cooperative learning activities that will value their strong points, counselling sessions, group activities (formal and informal groups), cultural activities and psychotherapy to increase selfesteem and reduce anxiety. The reliability of the scale was evaluated with Cronbach's alpha coefficient of internal consistency (Cronbach, 1951), alpha for 9 items being 0.824 , proving a good reliability of the scale as it is bigger than 0.7 (Cortina, 1993).

d. the activities that schools could implement for institutional development to facilitate the reintegration of the remigrant children (as the native children and the teachers perceive them), focusing on: training the teachers and staff for reintegrating the remigrants, having an adapted curriculum for the remigrant pupils, having adapted evaluation procedures and tools for the remigrant pupils, implementing parental counselling sessions for parents and hiring a professional school counsellor and train him for reintegrating the remigrants. The reliability of the scale was evaluated with Cronbach's alpha coefficient of internal consistency (Cronbach, 1951), alpha for 5 items being 0.710 , proving a good reliability of the scale as it is bigger than 0.7 (Cortina, 1993).

e. the instruments that schools could develop and use to facilitate the reintegration of the remigrant children (as the native children and the teachers perceive them), focusing on: handbooks for teachers, handbooks for remigrant pupils, counselling worksheets, optional courses, training for teachers and other staff (counsellor, speech therapist, etc.), informative materials for teachers on the social and educational effects of remigration, informative materials for pupils on the social and educational effects of remigration. The reliability of the scale was evaluated with Cronbach's alpha coefficient of internal consistency (Cronbach, 1951), alpha for 7 items being 0.811 , proving a good reliability of the scale as it is bigger than 0.7 (Cortina, 1993).

The items of the questionnaire were established through consulting with 
the school counsellors in C.J.R.A.E. Vrancea and based on the previous data from researches and direct interaction with teachers and remigrant children.

The score for each of the five aspects was calculated as mathematical average of the answers for the items addressing that aspect; the score for each dimension is between 1 - very low and 5 - very high.

\subsection{Subjects}

The total sample included 737 respondents, pupils and teachers from gymnasium (grades 5 to 8) and highschools (grades 9 to 12) in Vrancea county. The number of respondents in each category of subjects is presented in Table no. 1. The sample is not representative at national level, this limiting the generalisation of the results.

The selection of the subjects was made randomly from schools in Vrancea

Table no. 1. Number of subjects

\begin{tabular}{lccccccc}
\hline & $\begin{array}{c}\text { gymnasium } \\
\text { pupils }\end{array}$ & $\begin{array}{c}\text { highschool } \\
\text { pupils }\end{array}$ & $\begin{array}{c}\text { gymnasium } \\
\text { teachers }\end{array}$ & $\begin{array}{c}\text { highschool } \\
\text { teachers }\end{array}$ & pupils & \multirow{2}{*}{ teachers } \\
\hline male & 175 & 146 & 21 & 26 & $\mathbf{3 2 1}$ & $\mathbf{4 7}$ \\
\hline female & 164 & 150 & 36 & 19 & $\mathbf{3 1 4}$ & $\mathbf{5 5}$ \\
\hline TOTAL & 339 & 296 & 57 & 45 & $\mathbf{6 3 5}$ & $\mathbf{1 0 2}$ \\
\hline
\end{tabular}

county that are integrating remigrants and that are/were assisted by C.J.R.A.E. Vrancea in their efforts to facilitate the reintegration of the remigrants. Therefore, the respondents are colleagues of the remigrant children and teachers that work in class with remigrants (and natives, of course). Most of the respondents are from urban schools, but the research did not analyse the influence of this factor on the results, as the previous research (Luca, Foca, Gulei \& Brebule , 2012) showed little or no difference between the Romanian remigrants in rural and urban schools. 
The data was collected in the first semester of the 2018-2019 school year, through printed questionnaires administered in groups of pupils or teachers (never at the same time).

The research was conducted in Vrancea county because of the 2 previous researches that were conducted here regarding the difficulties of the remigrant children and the projects that are implemented at county level to facilitate the reintegration of the remigrants; also, the percentage of the remigrant pupils in the total population of this county $(2.52 \%)$ made this topic relevant for this geographical area.

\section{Findings}

3.1. The specific needs of the remigrant children (as native pupils and teachers perceive them)

Comparing the evaluation of the three categories of needs (total score, irrespective of the category of subjects), as presented in Table no. 2, we found statistically significant differences between the scores on cultural needs and psychological needs $(\mathrm{p}<0.001)$, cultural needs and educational needs ( $p<0.001)$, psychological needs and educational needs ( $<<0.001)$. The native pupils and teachers focus mainly on the cultural needs of the remigrant pupils, then on their psychological and social needs and last on their educational needs. These results confirm the findings in previous researches in Romania (Mitulescu, ăranu et al., 2017) showing that the main functions of schools that are hosting migrants are the facilitation of the cultural continuity and integration and the development of positive social skills; in the above mentioned research, the educational function of those schools is also at the bottom of the list.

Comparing the evaluations made by pupils and teachers we found that the psychological and social needs of the remigrants $(p=0.002)$ and the educational needs of the remigrants $(\mathrm{p}=0.008)$ are more obvious for teachers than for the native pupils, while the cultural needs are similarly evaluated by the two categories of respondents. 
Table no. 2. Perceived psychological, cultural and educational needs of the remigrant pupils - average scores

\begin{tabular}{lcccccc}
\hline & $\begin{array}{c}\text { gymnasium } \\
\text { pupils }\end{array}$ & $\begin{array}{c}\text { highschool } \\
\text { pupils }\end{array}$ & $\begin{array}{c}\text { gymnasium } \\
\text { teachers }\end{array}$ & $\begin{array}{c}\text { highschool } \\
\text { teachers }\end{array}$ & pupils & teachers \\
\hline $\begin{array}{l}\text { psychological and } \\
\text { Social needs }\end{array}$ & 2.92 & 3.10 & 3.41 & 3.35 & $\mathbf{3 . 0 0}$ & $\mathbf{3 . 1 6}$ \\
\hline cultural needs & 3.25 & 3.23 & 3.61 & 3.25 & $\mathbf{3 . 2 4}$ & $\mathbf{3 . 2 3}$ \\
\hline educational needs & 2.87 & 2.99 & 3.32 & 3.21 & $\mathbf{2 . 9 3}$ & $\mathbf{3 . 0 5}$ \\
\hline
\end{tabular}

The psychological and social needs of the remigrants $(p=0.002)$ and the educational needs $(p=0.025)$ are more obvious for the older pupils (highschool) compared with the younger pupils (gymnasium), but the cultural needs are perceived is a similar way. The cultural needs of the remigrants are more obvious for gymnasium teachers compared with highschool teachers $(\mathrm{p}<0.001)$.

There is no significant gender effect: girls and boys / male and female teachers evaluate each category of needs of the remigrants in a similar way.

3.2. The effects of remigration in terms of educational behaviour (as native pupils and teachers perceive them)

Comparing the evaluation of the four potential effects (total score, irrespective of the category of subjects), as presented in Table no. 3, we found statistically significant differences, with skipping classes being perceived as less relevant compared with limited academic performance $(\mathrm{p}<0.001)$, with limited skills and competencies $(\mathrm{p}<0.001)$ and with limited involvement in extracurricular activities $(\mathrm{p}<0.001)$. According to those data, skipping classes is the least intense effect of remigration according to the native pupils and teachers, as they are focusing more on limited academic performance, limited skills and limited participation to extracurricular activities (without significant differences between the evaluation of those three potential effects). 
Table no. 3. Perceived effects of remigration - average scores

\begin{tabular}{lcccccc}
\hline & $\begin{array}{c}\text { gymnasium } \\
\text { pupils }\end{array}$ & $\begin{array}{c}\text { highschool } \\
\text { pupils }\end{array}$ & $\begin{array}{c}\text { gymnasium } \\
\text { teachers }\end{array}$ & $\begin{array}{c}\text { highschool } \\
\text { teachers }\end{array}$ & pupils & teachers \\
\hline $\begin{array}{l}\text { skip classes and } \\
\text { eventually quit } \\
\text { school }\end{array}$ & 2.30 & 2.75 & 3.16 & 3.24 & $\mathbf{2 . 5 1}$ & $\mathbf{2 . 9 3}$ \\
\hline $\begin{array}{l}\text { have a limited } \\
\text { academic } \\
\text { performance }\end{array}$ & 2.89 & 2.90 & 3.68 & 3.53 & $\mathbf{2 . 9 0}$ & $\mathbf{3 . 1 9}$ \\
\hline $\begin{array}{l}\text { develop limited } \\
\text { skills and } \\
\text { competencies }\end{array}$ & 2.91 & 3.14 & 3.42 & 3.20 & $\mathbf{3 . 0 1}$ & $\mathbf{3 . 1 1}$ \\
\hline $\begin{array}{l}\text { limit their } \\
\text { involvement in } \\
\begin{array}{l}\text { extracurricular } \\
\text { activities }\end{array}\end{array}$ & 2.86 & 3.20 & 3.40 & 3.07 & $\mathbf{3 . 0 2}$ & $\mathbf{3 . 0 3}$ \\
\hline
\end{tabular}

Comparing the evaluations made by pupils and teachers we found that teachers evaluate skipping classes $(\mathrm{p}<0.001)$ and limited academic performance $(\mathrm{p}<0.001)$ as being less plausible compared with pupils, while limited skills and limited participation to extracurricular activities are evaluated in a similar way by teachers and native pupils.

Highschool pupils have a general tendency of evaluating the effects of remigration as being more intense compared with gymnasium pupils: skipping classes $(\mathrm{p}<0.001)$, limited skills and competencies $(\mathrm{p}=0.010)$ and limited involvement in extracurricular activities $(\mathrm{p}=0.001)$ are perceived as being more plausible for older children compared with younger children.

Highschool teachers and gymnasium teachers have similar evaluation of all the potential effects of remigration.

There is no significant gender effect: girls and boys/male and female teachers each evaluate potential effects of remigration in a similar way. 
3.3. The activities that schools could implement for the remigrant children (as native pupils and teachers perceive them)

The respondents evaluated a list of nine activities and specific ways of organizing the didactic activities that was established by the researcher based on previous interactions with remigrants and their teachers; the list is not exhaustive and the respondents had the opportunity to add other activities that they consider to be effective in integrating the remigrants, but the number of those additional information was insignificant.

Table no. 4. Activities and specific ways of organizing the didactic activities that schools could implement for the remigrant pupils-average score

\begin{tabular}{|c|c|c|c|c|c|c|}
\hline & $\begin{array}{c}\text { gymnasium } \\
\text { pupils }\end{array}$ & $\begin{array}{l}\text { highschool } \\
\text { pupils }\end{array}$ & $\begin{array}{c}\text { gymnasium } \\
\text { teachers }\end{array}$ & $\begin{array}{c}\text { highschool } \\
\text { teachers }\end{array}$ & pupils & teachers \\
\hline $\begin{array}{l}\text { linguistic } \\
\text { preparation } \\
\text { classes }\end{array}$ & 4.16 & 4.10 & 4.39 & 4.36 & 4.13 & 4.24 \\
\hline $\begin{array}{l}\text { additional } \\
\text { classes and } \\
\text { activities for } \\
\text { some school } \\
\text { subjects }\end{array}$ & 3.80 & 3.65 & 4.32 & 4.13 & 3.73 & 4.03 \\
\hline $\begin{array}{l}\text { extracurricular } \\
\text { activities and } \\
\text { learning in } \\
\text { informal context } \\
\text { activities }\end{array}$ & 3.50 & 3.74 & 4.11 & 4.22 & 3.61 & 3.97 \\
\hline $\begin{array}{l}\text { project based } \\
\text { learning } \\
\text { experiences }\end{array}$ & 3.71 & 3.78 & 4.00 & 4.00 & 3.75 & 3.91 \\
\hline $\begin{array}{l}\text { cooperative } \\
\text { learning } \\
\text { activities that } \\
\text { will value their } \\
\text { strong points }\end{array}$ & 3.99 & 3.93 & 4.44 & 3.98 & 3.96 & 4.22 \\
\hline $\begin{array}{l}\text { counselling } \\
\text { sessions }\end{array}$ & 3.34 & 3.56 & 4.32 & 4.09 & 3.44 & 3.91 \\
\hline $\begin{array}{l}\text { group activities } \\
\text { (formal and } \\
\text { informal groups) }\end{array}$ & 3.59 & 3.75 & 4.05 & 4.09 & 3.66 & 3.97 \\
\hline $\begin{array}{l}\text { cultural } \\
\text { activities }\end{array}$ & 3.54 & 3.46 & 4.21 & 4.00 & 3.50 & 3.89 \\
\hline $\begin{array}{l}\text { psychotherapy } \\
\text { to increase } \\
\text { self-esteem and } \\
\text { reduce anxiety }\end{array}$ & 3.66 & 3.68 & 4.09 & 4.20 & 3.67 & 3.91 \\
\hline
\end{tabular}


Comparing the evaluation of the nine school activities that could help remigrant pupils to reintegrate (total score, irrespective of the category of subjects), as presented in Table no. 4, we found some significant differences showing that linguistic preparation classes is considered significantly more relevant than all the other activities (confirming that the native pupils and the teachers are focusing on the need of the remigrants to learn to speak Romanian as the most important condition for their reintegration in the Romanian schools), followed by the cooperative learning activities; the rest of seven activities are evaluated in a similar way by the respondents.

The accent on linguistic preparation classes is coherent with the results of the previous research in Romania that emphasized on the lack of training of teachers of Romanian as foreign language and the limited financial and pedagogical resources for those classes in Romanian schools (Mitulescu, ăranu et al., 2017).

Comparing the evaluations made by pupils and teachers we found that there is a general tendency of the teachers to evaluate all the activities as being more relevant and important compared with the pupils'; there is only one exception, as linguistic preparation classes are evaluated similarly by teachers and native pupils.

Highschool pupils and gymnasium pupils evaluate the activities is a similar way, with the exception of extracurricular activities $(\mathrm{p}=0.007)$ and counselling sessions $(\mathrm{p}=0.020)$ that are more important to older pupils compared with younger pupils.

Highschool teachers and gymnasium teachers evaluate the activities in a similar way, with only one exception, the cooperative learning activities being more important for the gymnasium teachers.

There is a significant gender effect in children population, with girls evaluating almost all the activities (with the exception of the cultural activities) as being more important compared with the boys. This gender effect is not significant in the teachers' population. 
3.4. The activities that schools could implement for institutional development (as native pupils and teachers perceive them)

Comparing the evaluation of the five school activities for the institutional development (total score, irrespective of the category of subjects), as presented in Table no. 5, we revealed a clear hierarchy regarding the most important activities for the institutional development in Romania in order to facilitate the reintegration of the remigrant children: 1. training the teachers; 2 . having a professional school counsellor \& having an adapted curriculum; 3. having adapted evaluation procedures \& having parental counselling.

Table no. 5. Activities that schools could implement for the institutional development - average scores

\begin{tabular}{|c|c|c|c|c|c|c|}
\hline & $\begin{array}{c}\text { gymnasium } \\
\text { pupils }\end{array}$ & $\begin{array}{l}\text { highschool } \\
\text { pupils }\end{array}$ & $\begin{array}{c}\text { gymnasium } \\
\text { teachers }\end{array}$ & $\begin{array}{l}\text { highschool } \\
\text { teachers }\end{array}$ & pupils & teachers \\
\hline $\begin{array}{l}\text { train teachers } \\
\text { and staff for } \\
\text { reintegrating } \\
\text { the remigrants }\end{array}$ & 3.85 & 3.89 & 4.35 & 4.11 & 3.87 & 4.27 \\
\hline $\begin{array}{l}\text { have an adapted } \\
\text { curriculum } \\
\text { for remigrant } \\
\text { pupils }\end{array}$ & 3.49 & 3.65 & 4.30 & 4.31 & 3.56 & 4.06 \\
\hline $\begin{array}{l}\text { have an adapted } \\
\text { evaluation } \\
\text { procedures \& } \\
\text { tools for } \\
\text { remigrants }\end{array}$ & 3.35 & 3.53 & 4.33 & 4.18 & 3.43 & 3.99 \\
\hline $\begin{array}{l}\text { implement } \\
\text { parental } \\
\text { counselling } \\
\text { sessions for } \\
\text { remigrants } \\
\text { parents }\end{array}$ & 3.21 & 3.48 & 4.42 & 4.44 & 3.34 & 4.05 \\
\hline $\begin{array}{l}\text { hire a school } \\
\text { counsellor and } \\
\text { train him for } \\
\text { reintegrating } \\
\text { the remigrants }\end{array}$ & 3.54 & 3.75 & 4.39 & 4.24 & 3.64 & 4.03 \\
\hline
\end{tabular}


Of course, one can argue the capacity of pupils to objectively evaluate the activities that schools could implement and the general schools' strategy, as it is obvious that especially the gymnasium pupils lack the cognitive abilities and the information to do so. Still, we should take into consideration that this research does not analyse their opinion as "experts", but only analyses their perception in order to let the educational experts make decisions based on this specific perception. Of course, a school should not necessarily organize teachers' training just because the pupils asked for this activity, but they should take pupils' opinion into consideration when deciding if training is necessary or not. Therefore, these results should be treated with caution due the low ability of pupils to objectively evaluate these dimensions, but are still important for the decision makers.

Comparing the evaluations made by pupils and teachers we found that teachers consider all the activities as being more important compared with the children's, being more focused on the institutional development and more receptive to activities that could provide this development.

Highschool pupils have a general tendency of making higher evaluation of all those activities compared with gymnasium pupils, with statistically significant differences for adapted evaluation procedures $(\mathrm{p}=0.036)$, parental counselling $(\mathrm{p}=0.006)$ and school counselling $(\mathrm{p}=0.038)$.

Highschool teachers and gymnasium teachers evaluate the activities in a similar way, with no significant differences.

\subsection{The instruments to facilitate the reintegration of the remigrant} children (as native pupils and teachers perceive them)

Comparing the evaluation of the seven instruments that could help remigrant pupils to reintegrate (total score, irrespective of the category of subjects), as presented in Table no. 6, we found significant differences that suggest a hierarchy: 1 . handbooks for the remigrant pupils; 2 . counselling worksheets \& optional courses \& training for teachers \& informative materials for teachers $\&$ informative materials for pupils; 3 . handbooks for teachers. 
Table no. 6. Instruments that schools could use to facilitate the reintegration of the remigrant pupils - average scores

\begin{tabular}{llccccc}
\hline & $\begin{array}{c}\text { gymnasium } \\
\text { pupils }\end{array}$ & $\begin{array}{c}\text { highschool } \\
\text { pupils }\end{array}$ & $\begin{array}{c}\text { gymnasium } \\
\text { teachers }\end{array}$ & $\begin{array}{c}\text { highschool } \\
\text { teachers }\end{array}$ & pupils & teachers \\
\hline $\begin{array}{l}\text { handbooks for } \\
\text { teachers }\end{array}$ & 3.16 & 3.44 & 4.19 & 4.04 & $\mathbf{3 . 2 9}$ & $\mathbf{3 . 8 6}$ \\
\hline $\begin{array}{l}\text { handbooks for } \\
\text { remigrant pupils }\end{array}$ & 3.78 & 3.73 & 4.25 & 3.91 & $\mathbf{3 . 7 6}$ & $\mathbf{4 . 0 0}$ \\
\hline $\begin{array}{l}\text { counselling } \\
\text { worksheets }\end{array}$ & 3.36 & 3.56 & 4.44 & 4.16 & $\mathbf{3 . 4 6}$ & $\mathbf{4 . 0 1}$ \\
\hline $\begin{array}{l}\text { optional courses } \\
\text { training for }\end{array}$ & 3.43 & 3.58 & 4.28 & 4.02 & $\mathbf{3 . 5 0}$ & $\mathbf{3 . 8 9}$ \\
\hline $\begin{array}{l}\text { teachers and other } \\
\text { staff (counsellor, } \\
\text { speech therapist, } \\
\text { etc.) }\end{array}$ & 3.34 & 3.69 & 4.40 & 3.93 & $\mathbf{3 . 5 0}$ & $\mathbf{4 . 0 7}$ \\
\hline $\begin{array}{l}\text { informative } \\
\text { materials for } \\
\text { teachers on the } \\
\text { educational effects } \\
\text { of remigration }\end{array}$ & 3.43 & 3.66 & 4.23 & 3.73 & $\mathbf{3 . 5 4}$ & $\mathbf{4 . 0 0}$ \\
\hline $\begin{array}{l}\text { informative } \\
\text { materials for } \\
\text { pupils on the } \\
\text { educational effects } \\
\text { of remigration }\end{array}$ & 3.50 & 3.63 & 4.16 & 3.91 & $\mathbf{3 . 5 6}$ & $\mathbf{3 . 9 9}$ \\
\hline
\end{tabular}

As we mentioned before, the children's capacity to evaluate the school strategy and the instruments they should use is not necessarily very well developed (especially in gymnasium), so the results should be treated with caution; still, it is important for school management to know the pupils' opinion on this topic, as the insight they bring could not be accessible for the decision makers and even for the teachers.

Gymnasium teachers made higher evaluation compared with high school teachers, with statistically significant differences for teacher training $(p=0.005)$ and informative materials for teachers $(p=0.010)$. This bigger need perceived by the gymnasium teachers can be explained with reference to the number of remigrants in different educational levels, as Brebule (2018) showed that the number of the remigrant pupils in gymnasium is more than double compared with the number of the remigrant pupils in 
high schools (in Vrancea county, 38,93\% of the remigrants are enrolled in gymnasium while only $17,86 \%$ of the remigrants are enrolled in highschool).

\subsection{Research limits}

One important limit of the research is the number and the selection of the respondents, limiting the generalisation of the results to the analysed population; further analyses are required in order to have representative results for the Romanian educational system.

Another limit is related with the lower ability of children to evaluate the difficulties that the remigrant pupils have to face and the activities and instruments that schools should use to facilitate the integration of the remigrants. From an educational perspective, teachers have to understand that groups of pupils do not answer to the specific needs of the remigrants not necessarily because of lack of will or carelessness, but maybe because of the lack of understanding, and it is the teachers' role to make the native pupils understand how remigrant feel and think and help them reintegrate.

Another limit is related to the research methodology, as we assumed the investigation of the social perception of the effects of the remigration and the results do not reflect the actual difficulties the remigrant pupils have to face, but the way that native pupils perceive those difficulties.

\section{Discussion}

The remigration is a relatively new social phenomenon in Romania and in our schools, so teachers and native pupils are still discovering the educational impact of returning home and the need for institutional updates in the educational system in order to face this new challenge.

Teachers and native pupils are more receptive to the cultural and psychological needs of the remigrant children and less receptive to their educational needs (for pupils, it is maybe natural to have a more limited understanding of the educational needs of their remigrant colleagues). 
Common sense and public perception are focusing on the cultural and psychological shock associated with returning to the home country and focus less on the educational difficulties that the remigrant children have to face. According to the previous researches (Luca, Foca, Gulei \& Brebule ,2012), those educational difficulties are the most important issues for the remigrant pupils and their parents, as the children first face the difficulties in reenrolling in education (taking time and long procedures) and only after do they think about the social reintegration.

There is no doubt for anyone working in education that remigrant children face all three categories of difficulties (psychological, cultural and educational), with variable intensity. Still, remigrant pupils consider that the most important issues are the educational ones, the others (native pupils and teachers) focus more on the cultural and psychological difficulties of the remigrants.

These results emphasize the importance of really understanding the issues that the remigrants feel as important and accept that "the truth" about the consequences of remigration can be felt differently by the remigrant pupils, the native pupils and by teachers working with them.

In terms of the potential effects of the remigration, the social perception is less focusing on the dropout risk (that is a medium and long-term risk) than on the other educational risks (limited academic performance, limited skills and competencies, limited involvement in extracurricular activities, all of those being short-term effects, therefore more visible for the outside observers). Still, there are numerous researches showing a high risk of dropout in the population that started school in another country (Glick \& White, 2003; Rosenblum, Goldblatt \& Moin, 2008; Rumberger, 1995). Therefore, as expected, our results seem to reflect only the social perception of native pupils and teachers. This result is explained by the research methodology, as we investigated the social perception and not the actual effects of remigration.

The potential negative effects of remigration are less visible for teachers compared with pupils, especially regarding school dropout and limited academic performance. This status influence could be very important, 
considering that the decisions in education are made by the teachers, and they could take into consideration this bias effect while making decisions for facilitating the reintegration of remigrant pupils.

In terms of the activities that schools could implement for reintegrating the remigrants in education, the respondents consider as the most important the linguistic preparation classes, aspect that can be related with the low ability of the remigrants to understand text in Romanian language, even if that does not characterize all the remigrants (Brebule , 2018). Cooperative learning is also considered a very effective way to facilitate the reintegration of the remigrants, as a specific way to organize the learning activities that can be implemented by any teacher, irrespective of the decisions of the management or the systemic approach. The relevance of those activities is more visible for the teachers than for the pupils, so decision makers are aware of what schools and teachers could do for facilitating the educational integration of the remigrants.

In terms of institutional development, to better respond to the educational needs of the remigrants the respondents consider that the most important is to train the teachers, to hire a professional school counsellor and have an adapted curriculum; the perceived importance of those activities is higher for teachers compared with pupils, emphasizing the fact that teachers themselves are asking to be trained to adapt their didactic activities to the specific needs of the remigrants. Those results are confirming what Luca, Gulei, Foca and Brebule (2012) concluded regarding the lack of specific knowledge and procedures for reintegrating the remigrants, with teachers still asking to be trained to face this new educational phenomenon.

In terms of instruments that schools could develop and implement to facilitate the integration of the remigrants, the most important are considered to be handbooks for the remigrant pupils, counselling worksheets and optional courses. The tools for teachers - informative materials and handbooks are at the bottom of the list, even if teacher training is considered the most effective activity. Those results show that it is important to train the teachers, in terms of giving them resources and tools to work with pupils, not only information; a new perspective in teacher training is needed, focusing on practical activities and not on informing them - in this vision, the cooperative 
learning that was mentioned as an effective activity to integrate the emigrants could also be taken into consideration to train the teachers.

The need for instruments is more visible for teachers compared with pupils, for both tools for teachers and tools for pupils, and it should be like that considering that the development/selection of educational tools is the responsibility of teachers, not of pupils.

\section{Acknowledgement:}

The author would like to thank to University of Bucharest, Faculty of Psychology and Educational Sciences, in particular to Professor Gheorghe Tomşa, for creating the framework for the research within the doctoral studies programme.

This research was supported by Erasmus + 2018-1-RO01-KA201-049201 project. We thank our colleagues from Vrancea County Office for Resources and Educational Assistance who provided insight and expertise that greatly assisted the research, although they may not agree with all of the interpretations and conclusions of this paper.

\section{References}

- Ambrosini, W., Mayr, K., Peri, G., \& Radu, D. (2011). The selection of migrants and returnees: evidence from Romania and implications. Working paper 16912. Cambridge: National Bureau of Economic Research.

- Brebule , S.D. (2015). Scholar adaptation of re-migrated children. Proceedings of International Academic Conference on Social Sciences and Humanities in Prague 2015 (pp. 124-127). Praga: Czech Institute of Academic Education.

- Brebule, S.D. (2018). Consilierea educa ională a copiilor remigra i. Bucureşti: Editura Didactică şi Pedagogică.

- Cortina, J. (1993). What is coefficient alpha: an examination of theory and applications. Journal of applied psychology, 78(1), 98-104. https://doi.org/ 10.1037/0021-9010.78.1.98

- Cronbach, L. (1951). Coefficient alpha and the internal structure of tests. Psychomerika, 16(3), 297-334.

- Dustmann, C. (2003). Children and return migration. Journal of Population Economics, 16(4), 815-830. https://doi.org/10.1007/s00148-003-0161-2 
- Glick, J.E., \& White, M. (2003). The academic trajectories of immigrant youths: Analysis within and across cohorts. Demography, 40(4), 759-783. https://doi.org/10.1353/dem.2003.0034

- Luca, C., Foca, L., Gulei, A., \& Brebule , S. (2012). Metodologie de asisten $\breve{a}$ psihosocială a copiilor remigra $i$. Iaşi: Sedcom Libris.

- Mitulescu, S., ăranu, A.M., Alexandru, M., Gheorghe, O., Pătraşcu, A., Pascui, A., Scoda, A., Velea, S., \& Vargă, V. (2017). Educa ia copiilor afla $i$ sub protec ie interna ională. $O$ perspectivă a democratizării şcolii. Bucureşti: Editura Universitară.

- Popoiu, D. J., Gherasim, D. G., \& Brebule, S. D. (2018). Evaluarea strategiilor educa ionale de facilitare a reintegrării copiilor remigra $i$. Odobeşti: Editura Alternative Educa ionale.

- Rosenblum, S., Goldblatt, H., \& Moin, V. (2008). The Hidden Dropout Phenomenon among Immigrant High-School Students. School Psychology International, 29(1), 105-127.

- Rumberger, R. (1995). Dropping Out of Middle School: A Multilevel Analysis of Students and Schools. American Educational Research Journal, 32(3), 583625. https://doi.org/10.3102/00028312032003583

- Valtolina, G.G. (2013). Migrant children in Europe. The Romanian case. Amsterdam: IOS Press.

- UNESCO (2001). Universal Declaration on Cultural Diversity. Retrieved from http://unesdoc.unesco.org/images/0012/001271/127162e.pdf

The online version of this article can be found at: http://revped.ise.ro/category/2019-en/

\section{(c) $\overline{B Y-N C-B A}$}

This work is licensed under the Creative Commons Attribution-NonCommercial-ShareAlike 4.0 International License.

To view a copy of this license, visit http://creativecommons.org/licenses/by-nc-sa/4.0/ or send a letter to Creative Commons, PO Box 1866, Mountain View, CA 94042, USA.
Versiunea online a acestui articol poate fi găsită la: http://revped.ise.ro/category/2019-ro/

\section{$( c c ) \longdiv { D Y - N C - S A }$}

Această lucrare este licen iată sub Creative Commons Attribution-NonCommercial-ShareAlike 4.0 International License.

Pentru a vedea o copie a acestei licen e, vizita $i$ http://creativecommons.org/licenses/by-nc-sa/4.0/ sau trimite i o scrisoare către Creative Commons, PO Box 1866, Mountain View, CA 94042, SUA. 